\title{
The Effect of Fermented Completed Feed and Silage as a Forage Replacement in the Production and Milk Quality of Friesian Holstein Crossbred
}

\author{
M. Mirza Legawa, Ristianto Utomo, Cuk Tri Noviandi* and Andriyani Astuti
}

\author{
Department of Feed and Animal Nutrition, Faculty of Animal Science, Universitas Gadjah Mada, Jl. Fauna No. 3 , \\ Bulaksumur, Yogyakarta 55281 - Indonesia \\ *Corresponding author. Email: c.t.noviandi@ugm.ac.id
}

\begin{abstract}
This research was intended to identify the effect of fermented completed feed and silage as a forage replacement in the production and milk quality of Friesian Holstein crossbred. This research was used 6 of $3^{\text {rd }}-6^{\text {th }}$ month lactating dairy cows on average weight $386.2 \pm 30.3 \mathrm{~kg}$. The study consisted of 3 treatments, those were feeding concentrates + forages as usual given (R1; control), concentrate + silage (R2), and fermented complete feed (R3). The parameters observed were milk production and milk quality such as total solids, total solid non-fat, fat, and total protein of milk. This study used switchback design. Different means tested using Duncan's multiple range test. The results showed that the treatment of fermented complete feed (R3) and silage as a forage replacement (R2) was not significantly different $(\mathrm{P}>0.05)$ with control to the milk production $(12.37,11.93$, and $14.12 \mathrm{~L} /$ day), total solid $(11.60,12.60$, and $11.40 \%)$, total solid non-fat $(7.40,8.50$, and $8.01 \%)$, fat $(4.10,4.20$, and $3.30 \%)$ and total protein of milk $(2.71,2.57$, and $2.54 \%)$. The research concluded that silage can be used as a substitute for forage feed by maintaining milk production and quality and fermented complete feed does not increase the production and quality of milk.
\end{abstract}

Keywords: Dairy cow, Fermented complete feed, Silage, Milk production, Milk quality.

\section{INTRODUCTION}

Milk is produced by lactating cattle, one of which is Holstein Friesian dairy cows. The ruminant feed consists of forage and concentrate. Forage contains structural carbohydrates that will be digested by rumen microbes to produce acetic acid and butyric acid. Acetic acid used for milk fat synthesis and butyric acid is used as energy for the synthesis of fatty acids and the formation of body tissues. The availability of forage in Indonesia, which is not continuous throughout the year, is a problem for ruminants. Forage is widely available in the rainy season but is limited to the dry season. Silage is one of forage conservation technology to fulfill the demand for feed during the dry season. Utomo [1] states that silage is a feed product that has a low $\mathrm{pH}$ value $(<4.2)$ from a controlled fermentation of forage.

Forage in Indonesia has low quality, so it will be inadequate to fulfill the nutrient requirement of animal. Concentrate feed is provided to overcome the nutrient deficiency. Concentrate feed in the rumen will be digested into propionate acid which will be used for milk synthesis. The provision of mixed feed with a certain balance between forage and concentrate that has been adjusted to the nutrient requirement is called complete feed. There are two kinds of complete feed, dry complete feed, and wet complete feed. A dry complete feed is usually made in a form of pellets, wafers, or flour, while the wet complete feed is the provision of a mixture of concentrates and forages in fresh conditions, or carried out in wet conditions fermented [1]. Complete fermented feed is a mixture of forage and/or other basal feed in fresh condition with concentrates, which are fermented in a certain time to increase digestibility as well as for conservation in a shorter time than silage.

The provision of fermented complete feed can improve feed efficiency because the animal does not have the opportunity to choose feed. As a result of the digestion process, fermentation will increase due to the activity of cellulolytic and hemicellulolytic bacteria. The provision of fermented complete feed can increase production and quality of milk. 


\section{MATERIALS AND METHOD}

\subsection{Materials}

The study was conducted using six lactating Friesian Holstein Crossbred (FHC) dairy cows between three to six months, around four years old, milk production between 9 to 18 liters/day, and body weight $386.2 \pm 30.3$ $\mathrm{kg}$. The cows are classified into three treatments. The first treatment as control feed (R1) was $15 \mathrm{~kg}$ cornstalk (estimated at $25 \% \mathrm{DM}$ plus $11 \mathrm{~kg}$ concentrate), second treatment (R2) was $11 \mathrm{~kg}$ cornstalk silage (estimated at DM 30\%) and $11 \mathrm{~kg}$ concentrate, and third treatment (R3) was $22 \mathrm{~kg}$ fermented complete feed (FCF) that was made from 11 cornstalks and $11 \mathrm{~kg}$ concentrate. Each treatment was added with the tofu waste as much as $3 \mathrm{~kg}$. The composition of the concentrate feed was listed in Table 1. Concentrates Period 2 and 3 different with period 1 , because the concentrated ingredient such as plant ceased production.

Table 1. Feed consumption

\begin{tabular}{|c|l|c|c|}
\hline \multirow{2}{*}{ No } & \multirow{2}{*}{ Feed ingredients } & \multicolumn{2}{|c|}{ Feeding percentage } \\
\cline { 3 - 4 } & & Period 1 & Period 2 \\
\hline 1 & $\begin{array}{l}\text { Warga Mulya's } \\
\text { Concentrate }\end{array}$ & 45.4 & - \\
\hline 2 & $\begin{array}{l}\text { Primavit } \\
{ }^{\circledR}\end{array}$ & - & 49.3 \\
\hline 3 & Concentrate & 18.2 & 28.2 \\
\hline 4 & Copran pollard & 9.1 & 8.4 \\
\hline 5 & Rice hull & 27.3 & - \\
\hline 6 & Kleci & - & 14.1 \\
\hline Total & 100 & 100 \\
\hline
\end{tabular}

\subsection{Method}

The feed was given 2 times a day, namely in the morning at 07.00 WIB and in the afternoon at 16.00 WIB. The study was divided into three periods, each period lasting for 5 weeks including adaptation. The adaptation was done in the first week, each period of feed replacement according to treatment. The study was conducted using a switchback design [2,3]. The description of the design used is presented in Table 2.

Milk production (L) per head per period was converted to one lactation period according to the

Table 2. Switchback design of this research

\begin{tabular}{|l|l|l|l|}
\hline \multirow{2}{*}{ Period } & \multicolumn{2}{|l|}{ Group } \\
\cline { 2 - 4 } & $\begin{array}{l}\text { Group I } \\
\text { Animal 1 } \\
\text { and 2 }\end{array}$ & $\begin{array}{l}\text { Group I } \\
\text { Animal 3 } \\
\text { and 4 }\end{array}$ & $\begin{array}{l}\text { Group III } \\
\text { Animal 5 } \\
\text { and 6 }\end{array}$ \\
\hline Period 1 & R2 & R3 & R1 \\
\hline Period 2 & R3 & R1 & R2 \\
\hline Period 3 & R1 & R2 & R3 \\
\hline
\end{tabular}

R1: Control, R2: silage, and R3: fermented complete feed $(\mathrm{FCF})$

percentage per lactation month: first, second, third, fourth, fifth, sixth, seventh, seventh, ninth, and ninth months ten in: $13,13,12,12,10,10,9,8,7$ and $6 \%$ respectivily [4]. The variables observed in this study were feed intake, milk production (L) which was converted to one lactation period. Milk quality includes density, dry matter, solid non-fat, crude fat, and crude protein.

\subsubsection{Silage Making}

Cornstalk was chopped using the chopper to uniform size about 3 to $5 \mathrm{~cm}$. The cornstalks are then withered until moisture content about $65 \%$ and mixed with

Table 3. Chemical composition of feed

\begin{tabular}{|c|c|c|c|c|c|c|c|}
\hline \multirow[t]{2}{*}{ Feed } & \multirow[t]{2}{*}{ Period } & \multirow{2}{*}{$\begin{array}{l}\text { Dry matter } \\
(\%)\end{array}$} & \multicolumn{5}{|c|}{ Nutrient content (\% dry matter) } \\
\hline & & & $\mathrm{CP}$ & EE & CF & $\overline{N F E}$ & $\mathrm{TDN}^{1}$ \\
\hline \multirow[t]{3}{*}{ R1 } & 1 & 56.72 & 11.79 & 3.40 & 23.24 & 48.64 & 60.65 \\
\hline & 2 & 58.94 & 9.77 & 2.12 & 21.02 & 50.37 & 60.77 \\
\hline & 3 & 58.94 & 9.77 & 2.12 & 21.02 & 50.37 & 60.77 \\
\hline \multicolumn{2}{|c|}{ Average } & & 58.20 & 10.44 & 2.55 & 21.76 & 49.79 \\
\hline \multirow[t]{3}{*}{ R2 } & 1 & 46.97 & 10.88 & 3.20 & 21.42 & 52.52 & 62.27 \\
\hline & 2 & 51.64 & 10.43 & 2.32 & 22.77 & 49.60 & 62.83 \\
\hline & 3 & 51.64 & 10.43 & 2.32 & 22.77 & 49.60 & 62.83 \\
\hline \multicolumn{2}{|c|}{ Average } & & 50.08 & 10.58 & 2.61 & 22.32 & 50.57 \\
\hline \multirow[t]{3}{*}{ R3 } & 1 & 43.08 & 10.37 & 5.24 & 21.63 & 51.46 & 61.24 \\
\hline & 2 & 54.29 & 12.10 & 4.48 & 19.23 & 49.94 & 61.38 \\
\hline & 3 & 54.29 & 12.10 & 4.48 & 19.23 & 49.94 & 61.38 \\
\hline \multicolumn{2}{|c|}{ Average } & & 50.55 & 11.52 & 4.73 & 20.03 & 50.45 \\
\hline
\end{tabular}

DM: dry matter, CP: crude protein, EE: extract ether, CF: crude fiber, NFE: nitrogen-free extract

${ }^{1)} \mathrm{TDN}$ : total digestible nutrients calculated using regression according to [5] 
Table 4. The effect of different feed on dry matter, crude protein, crude fiber, and total digestible nutrients intake (Kg)

\begin{tabular}{|c|c|c|c|c|c|}
\hline \multirow[t]{2}{*}{ Variable } & \multirow[t]{2}{*}{ Period } & \multicolumn{4}{|c|}{ Nutrient content (\% dry matter) } \\
\hline & & $\mathrm{CP}$ & $\mathrm{EE}$ & $\mathrm{CF}$ & NFE \\
\hline \multirow[t]{4}{*}{ DM } & 1 & $16.45 \pm 0.00$ & $12.21 \pm 0.00$ & $10.77 \pm 0.00$ & $13.14 \pm 2.95$ \\
\hline & 2 & $17.09 \pm 0.00$ & $13.43 \pm 0.00$ & $10.88 \pm 0.00$ & $13.80 \pm 3.12$ \\
\hline & 3 & $17.09 \pm 0.00$ & $13.43 \pm 0.00$ & $13.57 \pm 0.00$ & $14.70 \pm 2.07$ \\
\hline & Average & $16.88^{\mathrm{a}} \pm 0.37$ & $13.02^{b} \pm 0.70$ & $11.74^{c} \pm 1.59$ & $13.88 \pm 2.48$ \\
\hline \multirow[t]{4}{*}{ CPns } & 1 & $1.94 \pm 0.00$ & $1.33 \pm 0.00$ & $1.12 \pm 0.00$ & $1.46 \pm 0.43$ \\
\hline & 2 & $1.67 \pm 0.00$ & $1.40 \pm 0.00$ & $1.32 \pm 0.00$ & $1.53 \pm 0.14$ \\
\hline & 3 & $1.67 \pm 0.00$ & $1.40 \pm 0.00$ & $1.64 \pm 0.00$ & $1.66 \pm 0.26$ \\
\hline & Average & $1.76 \pm 1.56$ & $1.38 \pm 0.04$ & $1.36 \pm 0.14$ & $1.55 \pm 0.27$ \\
\hline \multirow[t]{4}{*}{ CF } & 1 & $3.82 \pm 0.00$ & $2.62 \pm 0.00$ & $2.33 \pm 0.00$ & $2.92 \pm 0.79$ \\
\hline & 2 & $3.59 \pm 0.00$ & $3.06 \pm 0.00$ & $2.08 \pm 0.00$ & $2.91 \pm 0.77$ \\
\hline & 3 & $3.59 \pm 0.00$ & $3.06 \pm 0.00$ & $2.61 \pm 0.00$ & $3.09 \pm 0.49$ \\
\hline & Average & $3.67^{a} \pm 0.13$ & $2.91^{b} \pm 0.25$ & $2.34^{c} \pm 0.27$ & $2.97 \pm 0.61$ \\
\hline \multirow[t]{4}{*}{ TDN } & 1 & $9.98 \pm 0.00$ & $7.60 \pm 0.00$ & $6.60 \pm 0.00$ & $8.06 \pm 1.74$ \\
\hline & 2 & $10.39 \pm 0.00$ & $8.44 \pm 0.00$ & $6.68 \pm 0.00$ & $8.50 \pm 1.86$ \\
\hline & 3 & $10.39 \pm 0.00$ & $8.44 \pm 0.00$ & $8.33 \pm 0.00$ & $9.05 \pm 1.16$ \\
\hline & Average & $10.25^{a} \pm 0.24$ & $8.16^{b} \pm 0.48$ & $7.20^{c} \pm 0.98$ & $8.54 \pm 1.46$ \\
\hline
\end{tabular}

a,b,c: Different Superscript on the same row indicated significantly different $(\mathrm{P}<0.05)$.

ns : non-significant $(\mathrm{P}>0.05)$.

molasses as much as $5 \%$ of DM. The molasses used were dissolved in water with a ratio of $2: 1$. A mixture of cornstalk and molasses was then put into a plastic drum with a capacity of $80 \mathrm{~kg}$, while compacted, and fermented for 21 days.

\subsubsection{Fermented Complete Feed Making}

Fermented complete feed (FCF) was also conducted using basal feed cornstalk then added with concentrate with a ratio of $1: 1$. The ingredient of the concentrate used was the same as the concentrate was used on R1 and R2. Microbe starter in the form of $20 \mathrm{ml}$ "Saus Burger Pakan" (SBP®), plus $500 \mathrm{ml}$ of molasses dissolved in 3 liters of water were added to $1,000 \mathrm{~kg}$ of cornstalk and mixed until homogenous. The mixture then put into an $80 \mathrm{~kg}$ plastic drum, while compacted, and fermented for 7 days.

\section{RESULTS AND DISCUSSION}

Table 3 showed the results of the chemical composition of feed and the calculation of TDN for treatments R1, R2, and R3. The crude protein content between R1, R2, and R3 is relatively similar, between 10.44-11.55\%. Likewise, the TDN content between R1, $\mathrm{R} 2$, and R3 is relatively the same between $60.77-62.88 \%$.

Table 4 showed the dry matter intake (DMI), crude protein intake (CPI), crude fiber intake, (CFI) and total digestible nutrients intake (TDNI) of R1, R2, and R3 feed treatments. From the table we know that the R1 treatment has higher intake of DM, CP, CF, and TDN than R2 and $\mathrm{R} 3$. This difference among treatment related to the higher content of dry matter (DM) R1 than R2 and R3 (Table 3). In R2 and R3, the fermentation process occurs so that the $\mathrm{DM}$ content decreases, through the fermentation process.

Table 5. The effect of different feed on milk production

\begin{tabular}{|l|l|l|l|l|}
\hline \multirow{2}{*}{ Period } & \multicolumn{2}{|c|}{ Milk production during one lactation period (liter) } & \multirow{2}{*}{ Average $^{\text {ns }}$} \\
\cline { 2 - 4 } & R1 & R2 & R3 & \\
\hline 1 & $3,321 \pm 1,514.6$ & $3,075 \pm 318.2$ & $3,758 \pm 200.1$ & $3,385 \pm 763.5$ \\
\hline 2 & $4,830 \pm 254.6$ & $3,457 \pm 1,156.1$ & $3,640 \pm 917.1$ & $3,976 \pm 944.9$ \\
\hline 3 & $3,960 \pm 622.3$ & $4,385 \pm 318.2$ & $3,920 \pm 1,159.7$ & $4,088 \pm 647.9$ \\
\hline Average & $4,037 \pm 1,004.1$ & $3,639 \pm 819.1$ & $3,773 \pm 678.9$ & $3,816 \pm 811.4$ \\
\hline
\end{tabular}


Table 6. The effect of different feed on milk composition (\%DM)

\begin{tabular}{|c|c|c|c|c|c|}
\hline \multirow[t]{2}{*}{ Variable } & \multirow[t]{2}{*}{ Period $^{\text {ns }}$} & \multicolumn{4}{|l|}{ Feed $^{\text {ns }}$} \\
\hline & & R1 & $\mathrm{R} 2$ & R3 & Average \\
\hline \multirow{4}{*}{$\begin{array}{l}\text { Specific } \\
\text { gravity }\end{array}$} & 1 & $1.0220 \pm 0.003$ & $1.0240 \pm 0.002$ & $1.0250 \pm 0.003$ & $1.0237 \pm 0.002$ \\
\hline & 2 & $1.0245 \pm 0.001$ & $1.0230 \pm 0.000$ & $1.0255 \pm 0.001$ & $1.0243 \pm 0.001$ \\
\hline & 3 & $1.0245 \pm 0.002$ & $1.0250 \pm 0.000$ & $1.0220 \pm 0.004$ & $1.0238 \pm 0.003$ \\
\hline & Average & $1.0237 \pm 0.002$ & $1.0240 \pm 0.001$ & $1.0242 \pm 0.003$ & $1.0239 \pm 0.002$ \\
\hline \multirow[t]{4}{*}{ Fat } & 1 & $3.30 \pm 0.35$ & $3.40 \pm 0.14$ & $3.00 \pm 0.00$ & $3.20 \pm 0.25$ \\
\hline & 2 & $3.90 \pm 0.07$ & $3.60 \pm 0.00$ & $3.50 \pm 0.14$ & $3.70 \pm 0.18$ \\
\hline & 3 & $2.90 \pm 0.07$ & $5.50 \pm 4.24$ & $5.90 \pm 3.04$ & $4.70 \pm 0.28$ \\
\hline & Average & $3.30 \pm 0.48$ & $4.20 \pm 2.16$ & $4.10 \pm 1.93$ & $3.90 \pm 1.64$ \\
\hline \multirow{4}{*}{$\begin{array}{l}\text { Total } \\
\text { Solid }\end{array}$} & 1 & $10.90 \pm 0.85$ & $11.40 \pm 0.28$ & $10.90 \pm 0.57$ & $11.10 \pm 0.54$ \\
\hline & 2 & $11.90 \pm 0.42$ & $11.80 \pm 0.64$ & $11.60 \pm 0.14$ & $11.80 \pm 0.37$ \\
\hline & 3 & $11.03 \pm 0.14$ & $14.80 \pm 2.33$ & $12.20 \pm 1.77$ & $12.70 \pm 2.07$ \\
\hline & Average & $11.40 \pm 0.62$ & $12.60 \pm 1.97$ & $11.60 \pm 1.00$ & $11.90 \pm 1.37$ \\
\hline \multirow{4}{*}{$\begin{array}{l}\text { Solid non } \\
\text { fat }\end{array}$} & 1 & $7.70 \pm 0.50$ & $8.00 \pm 0.42$ & $7.90 \pm 0.57$ & $7.90 \pm 0.42$ \\
\hline & 2 & $8.10 \pm 0.35$ & $8.20 \pm 0.64$ & $8.10 \pm 0.28$ & $8.10 \pm 0.35$ \\
\hline & 3 & $8.50 \pm 0.21$ & $9.30 \pm 6.58$ & $6.30 \pm 1.27$ & $8.00 \pm 3.29$ \\
\hline & Average & $8.01 \pm 0.46$ & $8.50 \pm 3.02$ & $7.40 \pm 1.09$ & $8.00 \pm 1.81$ \\
\hline \multirow[t]{4}{*}{ Protein } & 1 & $2.37 \pm 0.03$ & $2.55 \pm 0.03$ & $2.68 \pm 0.18$ & $2.53 \pm 0.16$ \\
\hline & 2 & $2.85 \pm 0.15$ & $2.58 \pm 0.08$ & $2.85 \pm 0.18$ & $2.76 \pm 0.18$ \\
\hline & 3 & $2.53 \pm 0.01$ & $2.58 \pm 0.17$ & $2.61 \pm 0.29$ & $2.57 \pm 0.16$ \\
\hline & Average & $2.59 \pm 0.23$ & $2.57 \pm 0.09$ & $2.71 \pm 0.21$ & $2.62 \pm 0.19$ \\
\hline
\end{tabular}

a,b,c: Different Superscript on the same row indicated significantly different $(\mathrm{P}<0.05)$.

ns : non-significant $(\mathrm{P}>0.05)$.

Wulandari et al. [6] stated that the fermentation process in feed can cause a decrease in the total dry matter content caused by respiration and fermentation. Daily milk production data generated, carried over to one lactation using the formula [4]. The milk production during the one lactation period produced by the treatments: R1, R2, and $\mathrm{R} 3$ are listed in Table 5.

Table 5 shows that milk production between treatments was not significantly different. This shows that the provision of silage and fermented complete feed did not have a negative effect on milk production. The milk production of $\mathrm{R} 1$ treatment was 4,307 liters (14.121 L/day), R2 3,639 liters (11.931 L/day), and R3 3,773 liters (12.370 L/day).

Dry matter intake $(\mathrm{kg})$, crude protein intake $(\mathrm{kg})$ and TDN intake $(\mathrm{kg})$ at $\mathrm{R} 1$ was higher $(\mathrm{P}<0.05)$ than $\mathrm{R} 2$ and $\mathrm{R} 3$, but milk production between R1, R2, and R3 was not significantly different. This related to the $\mathrm{R} 2$ and $\mathrm{R} 3$ have undergone a fermentation process so that it has a higher digestibility value than the $\mathrm{R} 1$ that has not undergone the fermentation process. Zubaili et al. [7] stated that fermented complete feed has a higher dry matter and organic matter digestibility than unfermented feed.
Table 6 shows the density of milk produced between treatments R1, R2, and R3 were not significantly different. This shows that nutrient intake among treatment was the same. However, it turns out that R3 produced average $1.0239 \pm 0.002$ below the standard made by the National Standards Agency (SNI) that is 1.0270. Low milk density can be caused by a lack of minerals and the high fat it contains, which means lack of mineral feed. Alcantara et al. [8] stated that density values decreased as temperature, moisture and fat contents increased; and increased as lactose, protein and minerals contents increased.

Milk fat levels for each treatment are presented in Table 6. Milk fat between treatments R1, R2 and R3 were not significantly different $(\mathrm{P}>0.05)$. The level of fat $(\%)$ produced between treatments averaged 3.90 \pm 1.6 , higher than the standard set by the National Standards Agency (2011), which is a minimum of $3 \%$. The level of milk fat was influenced by the level of milk production. Milk production was negatively correlated with fat content. The higher milk production, the lower the fat content. The increasing percentage of milk production will be followed by a decrease in milk fat content [9]. The feed 
given comes from the same feed ingredients, especially the basal feed. This situation allows the level of milk fat produced between treatments is not significantly different, because acetic acid as a precursor of milk fat produced also comes from cornstalk

The levels of total solids (TS) of milk for each treatment are listed in Table 6. The total solid of milk between the treatments of R1, R2, and R3 were not significantly different. The total solid levels (\%) produced between treatments averaged 11.90ะ1.37. Utami et al. [10] state that a good quality milk, which has a total solid content of more than $11.3 \%$ and the antibiotic content in milk is negative. Vergi et al. [11] state that the fat content is directly proportional to the content of total solids. The higher the fat content of milk, the higher the total solid.

The levels of solid non-fat (SNF) of milk for each treatment are presented in Table 6. The SNF between treatments R1, R2, and R3 showed no significant difference. Levels of solid non-fat (\%) produced between treatments are on average $8.00 \pm 1.81$ higher than the standards set by the National Standards Agency (2011) which is a minimum of $7.8 \%$. Solid non-fat levels in milk are influenced by the levels of milk fat produced. The levels of milk fat between treatments were not significantly different, so the SNF levels also followed. Zamzami et al. [12] state that the greater the milk container, the smaller the solid non-fat produced.

Milk protein levels for each treatment are presented in Table 6. Milk protein between treatments R1, R2, and R3 showed no significant difference. Protein content (\%) produced between treatments averaged $2.62 \pm 0.19$, lower than the standards set by the National Standards Agency (2011), which is a minimum of $2.8 \%$. The level of milk protein produced is influenced by the level of protein intake. Protein intake between treatments was not significantly different, so the levels of milk protein were also not significantly different. Syafri et al. [13] state that feeds protein consumed by an animal will be used for milk synthesis. Asrudin et al. [14] state that the milk protein content is more difficult to modify and tends to be related to genetic factors, so that differences in protein intake do not produce a real difference.

\section{CONCLUSION}

The use of cornstalk silage to replace cornstalk as basal feed was able to maintain production and quality of Friesian Holstein Crossbreds milk, even though the use of fermented complete feed was not able to improve production and quality of Friesian Holstein Crossbreds milk.

\section{REFERENCES}

[1] Utomo, R. 2015. Konservasi Hijauan Pakan dan Peningkatan Kualitas Bahan Pakan Berserat Tinggi. Gadjah Mada University Press. Yogyakarta.

[2] Astuti, A., A. Agus, and S.P.S. Budhi. 2009. The effect of high quality feed supplement addition on the nutrient consumption and digestibilitu of early lactating dairy cow. Buletin Peternakan. 33:81-87.

[3] Jones, B. and M. G. Kenward. 2003. Design and Analysis of Cross-Over Trials. Chapman and Hall/CRC. New York.

[4] Yaap W.W. 1955. Dairy Cattle Selection, Feeding and Management. Jonh Wiley \& Soons Inc. New York.

[5] Utomo, R. 2012. Evaluasi Pakan dengan Metode Noninvasif. Citra Aji Pramana. Yogyakarta. P 19.

[6] Wulandari, S., A. Agus, M. Soejono, M.N. Cahyanto, and R. Utomo. 2014. Performance of sheep fed cocoa pod based-fermented complete feed and its in vivo nutrients digestion. Buletin Peternakan. 38:42-50.

[7] Zubaili, Y. Usman, and S. Wajizah. 2017. Evaluation of in vitro digestibility of fermented complete feed based on sago residues as main diet by different incubation time. Jurnal Ilmiah Mahasiswa Pertanian Unsyiah. 2:350-358.

[8] Alcantara, L.A.P., R.C.I. Fontan, R.C.F. Bonomo, E.C. Souza, V.S. Sampaio, and R.G. Pereira. 2012. Density and dynamic viscosity of bovine milk affect by temperature and composition. International Journal of Food Engineering 8:1-12.

[9] Ramli, N., M. Ridla, T. Toharmat, and L. Abdullah. 2009. Milk yield and milk quality of dairy cow fed silage complete ration based on selected vegetables waste as fibre sources. J. Indom. Trop. Anim. Agric. $34: 36-41$.

[10] Utami, K.B., L.E. Radiati, dan P. Surjowardojo. 2014. Kajian kualitas susu sapi perah PFH (studi kasus pada anggota koperasi agro niaga di kecamatan Jabung kabupaten Malang). J. Ilmu-Ilmu Peternakan. 24:58-66.

[11] Vergi, M.D., T.H. Suprayogi dan S.M. Sayuthi. 2015. Kandungan lemak, total bahan kering dan bahan kering tanpa lemak susu sapi perah akibat interval pemerahan berbeda. Animal Agriculture Journal. 5:195-199.

[12] Zamzami, H.A., Hermawan, and L.B. Salman. 2015. The effect of using probiotic in complete feed on quantitiy and quality of milk production lactating dairy cows. Jurnal Universitas Padjadjaran. 4:1-13. 
[13] Syafri, A., D.W. Harjanti, and S.A.B. Santoso. 2014. Relationship between crude protein intake, milk production, milk protein and lactose of dairy cows at Salatiga district. Animal Agriculture Journal. 3:450-456.

[14] Asrudin, L.N.R., P. Sambodho, and D.W. Harjanti. 2014. Performans of milk production and milk quality produced at the highland and lowland of Semarang district. Animal Agriculture Journal. 3:592-598. 